\title{
PENGEMBANGAN PERANGKAT PEMBELAJARAN FISIKA MODEL GUIDED DISCOVERY LEARNING MENGGUNAKAN ALAT SEDERHANA UNTUK MEREDUKSI MISKONSEPSI SISWA SMA PADA MATERI FLUIDA STATIS
}

\author{
Alberto Yonathan Tangke Allo ${ }^{1)}$, Budi Jatmiko ${ }^{2)}$, Rudiana Agustini ${ }^{3)}$ \\ ${ }^{1)}$ Mahasiswa Prodi Pendidikan Sains Program Pascasarjana, Universitas Negeri Surabaya \\ ${ }^{2}$ Dosen Pascasarjana Prodi Pendidikan Sains Univestitas Negeri Surabaya \\ E-mail: jhntn909@gmail.com
}

\begin{abstract}
The purpose of this research is produce physics instructional materials based-on guided discovery model using simple equipment with criteria: valid, practical, and effective to reduce Senior High School students' misconceptions in static fluid. The development of instructional materials used four-D model and tested to three class are class X-2, class X-3, and class X-4 and involved 90 students at SMAN 19 Surabaya, second semester in academic year 2013/2014 with one group pretest - posttest design. The data collected include data instructional materials validation, data implementation of learning, data learning outcome, student's activity data, student's responses data, and data of documentations. The data analysis techniques used are: 1) quantitative descriptive analysis among others: completeness indicator, learning outcome, and reduction misconceptions. 2) analysis CRI among others: intensity misconceptions and reduction potential misconceptions. 3) analysis statistic parametric among others: normality test, homogeneity test, and paired t-test. The results of this research are: 1) the validity of instructional materials to develop is invalid category; 2) the instructional materials practicality in terms of: textbook students and exercise book students; the instructional materials in terms of a very good category; 3 ) the instructional material effectiveness in terms of: (a) mastery learning of classical 100\%; (b) reduction misconception the same as lowering misconception, the average result of students misconceptions reduction were class X-2 average $59,92 \%$, class X-3 average $24,52 \%$, class X-4 average $32,50 \%$; and (c) the students' responses to instructional materials are very positive. It's conclusion that the instructional materials through guided discovery learning model using simple equipment are valid, practical, and effective so worthy to reduce Senior High School Students misconceptions in static fluid materials.
\end{abstract}

\section{Keywords: Learning Material, Guided Discovery Learning, Misconceptions, and CRI}

\begin{abstract}
Abstrak: Penelitian ini bertujuan untuk menghasilkan perangkat pembelajaran fisika model guided discovery learning dengan menggunakan alat sederhana yang memenuhi kriteria: valid, praktis, dan efektif sehingga layak untuk mereduksi miskonsepsi siswa SMA pada materi fluida statis. Pengembangan perangkat pembelajaran menggunakan four-D model dan diujicobakan pada tiga kelas yaitu kelas X-2, kelas X-3, dan kelas X-4 dengan jumlah siswa seluruhnya sebanyak 90 siswa di SMA Negeri 19 Surabaya semester genap tahun ajaran 2013/2014 dalam bentuk one group pretest-posttest design. Data-data yang dikumpulkan berupa data validasi perangkat pembelajaran, data keterlaksanaan pembelajaran, data hasil belajar, data aktivitas siswa, data respons siswa, dan dokumentasi. Teknik analisis data yang digunakan antara lain: 1) analisis deskriptif kualitatif meliputi: ketuntasan indikator, hasil belajar, penurunan miskonsepsi. 2) analisis CRI meliputi: intensitas miskonsepsi dan penurunan potensi miskonsepsi. 3) analisis statistik parametrik meliputi: uji normalitas, uji homogenitas, dan uji-t. Hasil penelitian menunjukkan bahwa: 1) validitas perangkat pembelajaran yang dikembangkan berkategori valid; 2) kepraktisan perangkat pembelajaran ditinjau dari: keterbacaan BAS dan LKS berkategori tinggi, keterlaksanaan pembelajaran berkategori baik; 3) keefektifan perangkat pembelajaran ditinjau dari: (a) ketuntasan klasikal semua kelas mencapai 100\%; (b) reduksi miskonsepsi merujuk pada penurunan miskonsepsi yang dialami oleh rata-rata siswa kelas X-2 mencapai 59,29\%, kelas X-3 mencapai 24,52\%, kelas X-4 mencapai 32,50\%; dan (c) respons siswa terhadap perangkat dan pelaksanaan pembelajaran sangat positif. Berdasarkan hasil penelitian, dapat disimpulkan bahwa perangkat pembelajaran fisika model guided discovery learning menggunakan alat sederhana yang dikembangkan telah memenuhi kriteria validitas, kepraktisan, dan keefektifan sehingga layak digunakan untuk mereduksi miskonsepsi siswa SMA pada materi fluida statis.
\end{abstract}

Kata Kunci: Perangkat Pembelajaran, Guided Discovery Learning, Miskonsepsi, dan CRI.

\section{PENDAhUluAN}

Kurikulum 2013 adalah kurikulum pengembangan kompetensi peserta didik, yang menekankan pada penerapan pendekatan ilmiah (scientific approach) dalam proses pembelajaran. Pendekatan ilmiah dalam pembelajaran sebagaimana dimaksud meliputi: 
mengamati, menanya, mencoba, menalar, dan mengkomunikasikan untuk semua mata pelajaran (Kemendikbud, 2013).

Fisika merupakan salah satu cabang IPA, karena itu hakikat fisika dapat di tinjau dan dipahami dari hakikat IPA. Pelajaran fisika mempelajari gejala-gejala alam yang dalam memahaminya diperlukan aktivitas yang melibatkan siswa sebagai pusat pembelajaran. Pertama, siswa diajarkan bahan kajian yang ditujukan untuk berpikir/memacu keinginan hendak tahu siswa, dapat menemukan sendiri jawabannya, serta turut ambil bagian dalam proses mendapatkan pengetahuan. Kedua, kegiatan belajar mengajar fisika guru dituntut memperhatikan sikap siswa terhadap belajar, mendorong siswa untuk dapat memahami atau memecahkan sendiri masalah yang dihadapinya pada konsep fisika mulai dari yang sederhana sampai dengan yang kompleks. Siswa diharapkan pada tataran yang lebih tinggi, dapat menjelaskan contoh-contoh aplikatif dari prinsip dan konsep fisika yang telah menjadi bagian dari hidup mereka (Nur, 2008).

Guru perlu menyadari bahwa siswa pada saat memasuki tahap belajar yang baru, siswa tidak datang dengan pikiran yang kosong tanpa memiliki pengetahuan awal. Siswa mungkin telah memiliki pengetahuan dari pengalaman sehari-hari dan informasi dari lingkungan sekitar yang disebut sebagai konsep awal siswa (prakonsepsi) (Fajar \& Supardi, 2013). Konsep awal yang telah dimiliki siswa tentang fluida statis yang tidak sesuai dengan konsep ilmiah yang sudah disepakati oleh para ahli, keadaan demikian disebut dengan miskonsepsi. Miskonsepsi disebabkan oleh beberapa hal diantaranya dari siswa sendiri, guru yang mengajar, konteks pembelajaran, cara mengajar, dan buku teks (Suparno, 2005). Miskonsepsi tersebut umumnya sulit diatasi karena siswa cenderung mempertahankan konsep awal mereka secara kokoh (Ibrahim, 2012). Adanya miskonsepsi ini jelas akan sangat menghambat proses Kegiatan Belajar Mengajar (KBM) pada penerimaan dan asimilasi pengetahuanpengetahuan baru dalam diri siswa, sehingga akan menghalangi keberhasilan siswa dalam proses belajar lebih lanjut (Klammer, 1998).

Berg (1991) mengatakan bahwa miskonsepsi tidak dapat dihilangkan dengan metode ceramah, tanpa melalui proses belajar yang melibatkan siswa secara langsung dan aktif mencari solusi dari konflik kognitifnya. Siswa dilatih dalam proses konflik kognitif agar terjadi pertentangan dalam pikiran siswa sehingga mengalami fenomena yang bersifat "anomali". Metode pengolahan konflik kognitif bagi guru dan siswa merupakan hal yang sangat penting dalam pembelajaran karena konflik kognitif dapat mengarahkan pada hasil yang destruktif maupun konstruktif (Kim, 2006).
Berdasarkan pemahaman terhadap sebuah konsep, siswa dapat dikelompokkan ke dalam tiga jenis pemahaman, yaitu tahu konsep (TK), tidak tahu konsep (TTK), dan miskonsepsi (MK) (Hasan, Bagayoko, \& Kelly, 1999).

Peneliti telah melakukan observasi melalui tes diagnostik dan wawancara kepada guru fisika untuk mengidentifikasi miskonsepsi fluida statis dengan sasaran siswa yang telah mengalami pembelajaran materi fluida statis, yaitu siswa kelas XI IPA-4 diperoleh simpulan bahwa: pertama, hasil observasi tes diagnostik yaitu (1) rata-rata persentase siswa yang mengalami TK sebesar 38,37\%, TTK sebesar $17,40 \%$, dan MK sebesar 44,23\%; (2) sejumlah konsep pada materi fluida statis memberikan dampak yang kuat (mendalam) terhadap miskonsepsi siswa antara lain: (a) konsep massa jenis dialami oleh 46,52\% siswa, (b) konsep tekanan hidrostatis dialami oleh $32,60 \%$ siswa, (c) konsep prinsip Pascal dialami oleh 46,15\% siswa, dan (d) konsep prinsip Archimedes, dialami oleh $51,65 \%$ siswa. Kedua, hasil wawancara guru fisika yaitu (1) guru yang mengajar di kelas XI IPA-4 sangat kurang menggunakan inovasi sains dalam pembelajaran ke siswa; (2) pembelajaran di kelas masih didominasi oleh guru sebagai sumber informasi.

Model guided discovery learning menggunakan alat sederhana merupakan model pembelajaran yang berpusat pada siswa di mana dalam pembelajarannya menggunakan alat sederhana. Alat-alat sederhana ini dibuat dari bahan-bahan yang mudah didapat dan harganya sangat murah di masyarakat yang kemudian dirakit sendiri oleh peneliti menjadi suatu alat yang dapat digunakan dalam mereduksi miskonsepsi siswa pada materi fluida statis. Pada penelitian ini tidak menggunakan alat-alat praktikum yang sudah disediakan oleh pemerintah karena tidak semua sekolah dilengkapi dengan alat-alat praktikum yang memadai dan lengkap serta harganya sangat mahal.

Rasionalisasi penelitian ini menggunakan Kurikulum 2013 dengan model guided discovery learning pada siswa kelas X SMA yaitu Kurikulum 2013 menyarankan pembelajaran dengan pendekatan keterampilan sains, untuk mencapai keterampilan sains maka model pembelajaran yang sesuai salah satunya adalah model guided discovery learning. Model guided discovery learning menggunakan alat sederhana sangat sesuai untuk mengajarkan materi fluida statis dengan dasar bahwa dalam materi tersebut siswa dapat menemukan konsep-konsep dan prinsip-prinsip melalui proses mentalnya sendiri.

Siswa dalam menemukan konsep harus melakukan pengamatan, menggolongkan, membuat dugaan, menjelaskan, menarik kesimpulan. Melalui tahap-tahap penyelidikan dengan menggunakan alat sederhana 
dalam pembelajaran sehingga terbangun konsep ilmiah siswa dan dapat mereduksi miskonsepsi siswa. Akhirnya peneliti ingin merancangkan dan melakukan penelitian berjudul "Pengembangan Perangkat Pembelajaran Fisika Model Guided Discovery Learning Menggunakan Alat Sederhana untuk Mereduksi Miskonsepsi Siswa SMA pada Materi Fluida Statis",

Berdasarkan uraian latar belakang di atas, tujuan penelitian ini adalah menghasilkan suatu perangkat pembelajaran fisika model guided discovery learning menggunakan alat sederhana yang valid, praktis, dan efektif sehingga layak untuk mereduksi miskonsepsi siswa SMA pada materi fluida statis.

\section{METODE PENELITIAN}

Penelitian ini merupakan penelitian pengembangan karena mengembangkan perangkat pembelajaran yang diadaptasi dari four-D model (model 4-D) terdiri dari empat tahap yaitu tahap peratama, Define (pendefinisian); tahap kedua, Design (perancangan); tahap ketiga, Development (pengembangan); dan tahap keempat, Disseminate (penyebaran) (Thiagarajan dan Semmel, 1974).

Penelitian pengembangan perangkat yang dilakukan oleh peneliti hanya dari tahap pertama sampai ke tahap ketiga, dan tahap keempat peneliti tidak melalukannya, mengingat hasil pengembangan dikembangkan terbatas pada sekolah tempat penelitian yaitu SMA Negeri 19 Surabaya. Perangkat pembelajaran yang dikembangkan meliputi Rencana Proses Pembelajaran (RPP), Buku Ajar Siswa (BAS), Latihan Kerja Siswa (LKS) dan instrumen evaluasi (soal pretest dan soal posttest).

Subjek dalam penelitian ini adalah perangkat pembelajaran fisika model guided discovery learning menggunakan alat sederhana pada materi fluida statis. Sedangkan subjek uji coba pada uji coba I melibatkan 11 siswa dan pada uji coba II melibatkan 90 siswa, terdiri atas 3 kelas yaitu kelas X-2, kelas X-3, dan kelas X-4 di SMA Negeri 19 Surabaya.

Rancangan uji coba digunakan untuk mengujicobakan hasil pengembangan perangkat pembelajaran fisika model guided discovery learning menggunakan alat sederhana. Rancangan penelitian menggunakan rancangan one-group pretest-posttest design. Rancangan penelitian ini melibatkan satu kelompok yang diobservasi pada tahap pretest $\left(\mathbf{O}_{1}\right)$ yang kemudian dilanjutkan dengan perlakuan tertentu (X) dan posttest $\left(\mathbf{O}_{2}\right)$ (Sugiyono, 2014).

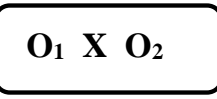

keterangan:

$\mathbf{O}_{1}$ adalah pretest untuk mengetahui penguasaan siswa terhadap materi pelajaran sebelum pembelajaran.

$\mathbf{O}_{2}$ adalah posttest untuk mengetahui penguasaan siswa terhadap materi pelajaran setelah pembelajaran.

$\mathbf{X}$ adalah perlakuan pembelajaran dengan menggunakan perangkat pembelajaran model guided discovery learning menggunakan alat sederhana.

Rancangan pengembangan perangkat pembelajaran model guided discovery learning menggunakan alat sederhana dideskripsikan dengan diagram alur pada Gambar 1.

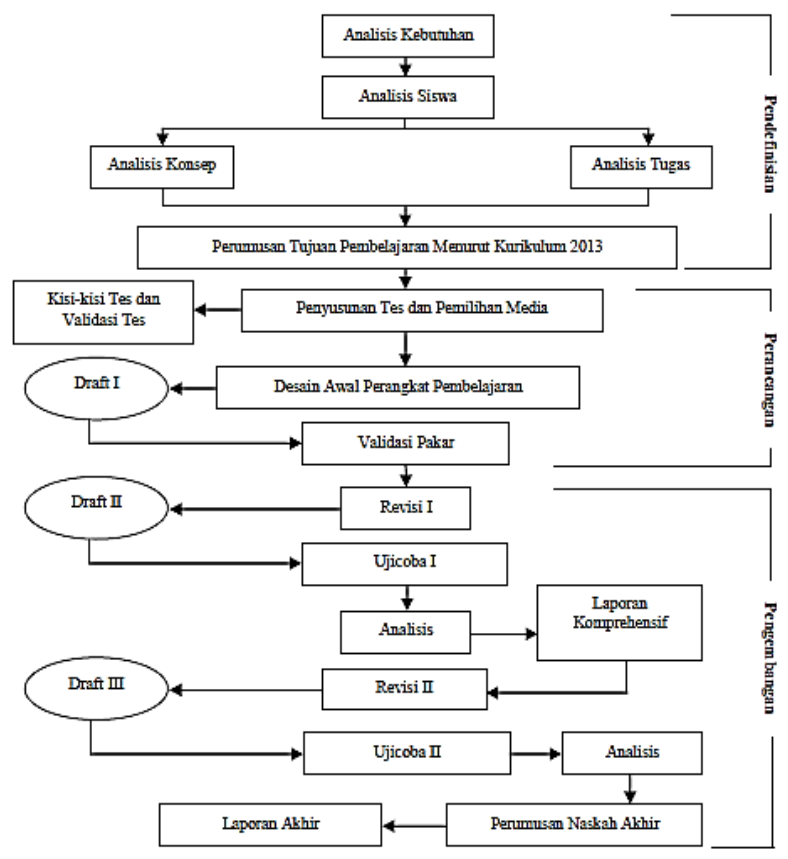

Gambar 1. Alur pengembangan perangkat pembelajaran penelitian diadaptasi dari model four-D model (Thiagarajan dan Semmel, 1974)

\section{A. Metode Pengumpulan Data}

Metode pengumpulan data digunakan untuk memeroleh data yang relevan, akurat, dan dapat digunakan dengan tepat sesuai tujuan penelitian. Metode pengumpulan data yang digunakan dalam dalam penelitian ini meliputi: 1) data keterlaksanaan RPP; 2) data hasil belajar; 3) data uji validasi; 4) data respons siswa; dan 5) data dokumentasi.

\section{B. Teknik Analisis Data}

Analisis data dalam penelitian ini dilakukan dengan menggunakan analisis deskriptif kuantitatif untuk mendeskripsikan data apa adanya dalam bentuk persentase dan menjelaskan data atau kejadian dengan kalimat-kalimat penjelasan secara kualitatif yang meliputi: 


\section{Analisis Validitas Perangkat Pembelajaran \\ Teknik analisis data validitas perangkat pembelajaran meliputi RPP, BAS LKS, dan tes miskonsepsi, menggunakan deskriptif kualitatif. Data yang diperoleh dianalisis dengan cara rata-rata skor tiap aspek menurut Ratumanan dan Laurens (2006).}

\section{Analisis Tingkat Keterbacaan BAS dan LKS}

Tingkat keterbacaan dianalisis melalui teknik close procedure. Teknik ini dilakukan dengan memberikan format baru yang mewakili sebagian kecil instrumen yang diukur. format baru tersebut, beberapa istilah penting dihilangkan atau dikosongkan, namun tidak menghilangkan makna dari kalimat itu sendiri. Persamaan analisis tingkat keterbacaan menurut Taylor (1953) seperti pada Persamaan 1:

$$
K_{B}=\frac{k}{\sum k} \times 100 \%
$$

Keterangan:

$$
\begin{aligned}
& K_{B}=\text { tingkat keterbacaan } \\
& k=\text { jumlah kata yang diisi benar } \\
& \sum k=\text { jumlah seluruh kata yang harus diisi }
\end{aligned}
$$

\section{Analisis Keterlaksanaan Pembelajaran}

Teknik analisis keterlaksanaan pembelajaran dilakukan oleh dua pengamat yang sudah memahami lembar pengamatan secara benar. Data yang diperoleh dianalisis secara deskriptif kuantitatif, selanjutnya hasil analisis tersebut dijabarkan dengan menggunakan analisis deskriptif kualitatif untuk memeroleh pernyataan yang menggambarkan kualitas angka-angka tersebut. Berdasarkan rata-rata penilaian dari dua pengamat untuk tiap aspek yang diamati akan ditentukan kategorinya menurut Suharsimi (2012).

$$
\begin{array}{ll}
\text { Tidak baik } & =1.00-1.99 \\
\text { Kurang baik } & =2.00-2.99 \\
\text { Cukup baik } & =3.00-3.49 \\
\text { Baik } & =3.50-4.00
\end{array}
$$

\section{Analisis Aktivitas Siswa}

Teknik analisis data pengamatan aktivitas siswa menggunakan deskriptif kuantitatif dan kualitatif. untuk memberikan deskripsi aktivitas siswa selama kegiatan pembelajaran dengan model pembelajaran guided discovery learning menggunakan alat sederhana. Data hasil pengamatan aktivitas siswa selama kegiatan pembelajaran dianalisis dengan menggunakan persentase. Rumus persentase aktivitas siswa menurut Arifin (2010) dapat disajikan dalam bentuk persamaan berikut.

$$
P=\frac{\sum R}{\sum N} \quad x 100 \%
$$

keterangan:

$P \quad:$ Persentase aktivitas siswa $\sum R:$ Jumlah frekuensi kategori pengamatan

$\sum N$ : Jumlah frekuensi seluruh kategori pengamatan

5. Analisis Respons Siswa

Analisis respons siswa yang diberikan dianalisis dengan menggunakan analisis deskriptif kuantitatif berupa persentase. Persentase tiap respons dihitung dengan menggunakan rumus:

$$
\text { Respons }=\left(\frac{\text { Jumlah aspek yang muncul }}{\text { Jumlah siswa }}\right) \times 100 \%
$$

Persentase respons siswa diadaptasi dari Riduwan (2010) dengan kriteria sebagai berikut:

$$
\begin{array}{ll}
0 \%-20 \% & =\text { Tidak Baik } \\
21 \%-40 \% & =\text { Kurang Baik } \\
41 \%-60 \% & =\text { Cukup Baik } \\
61 \%-80 \% & =\text { Baik } \\
81 \%-100 \% & =\text { Sangat Baik }
\end{array}
$$

\section{Analisis Hasil Belajar}

Hasil belajar pengetahuan siswa ditentukan dengan ketuntasan indikator tujuan pembelajaran, baik secara ketuntasan individual maupun ketuntasan klasikal. Secara individual siswa dikatakan tuntas apabila rata-rata ketercapaian indikator yang diwakili tujuan pembelajaran memenuhi Kriteria Ketuntasan Minimum (KKM) mata pelajaran fisika di SMA N 19 Surabaya yaitu nilai $\geq 75$. Ketika nilai minimal siswa mencapai 75 maka perlu diperhatikan nilai $N$-gain dari masing-masing siswa yang menunjukkan peningkatan hasil belajar fisika siswa sebelum dan setelah perlakuan.

$$
N-\text { Gain }=\frac{S_{\text {post }}-S_{\text {pre }}}{S_{\text {max }}-S_{\text {pre }}}
$$

keterangan:

$$
\begin{array}{ll}
N-\text { Gain } & =\text { nilai Gain } \\
\text { Spost } & =\text { nilai posttest } \\
\text { Spre } & =\text { nilai pretest } \\
\text { Smax } & =\text { nilai maksimal }
\end{array}
$$

Selanjutnya dari hasil perhitungan $N$ - Gain tersebut kemudian dikonversi dengan kriteria menurut Hake (1999) sebagai berikut:

Tabel 1. Kriteria Normalized Gain

\begin{tabular}{|l|l|}
\hline Skor $N$-Gain & Kriteria Normalized Gain \\
\hline $0.70<N$-Gain & Tinggi \\
\hline $0.30 \leq N$-Gain $\leq 0.70$ & Sedang \\
\hline$N$-Gain $<0.30$ & Rendah \\
\hline
\end{tabular}

\section{Analisis Penurunan Miskonsepsi}

Pengidentifikasian penurunan miskonsepsi siswa dapat dilakukan dengan cara menganalisis potensi miskonsepsi siswa pretest-posttest yang mengalami penurunan miskonsepsi secara individu, tetapi pada analisis kelompok digunakan rata-rata nilai $C R I$ tiap siswa. Rata-rata nilai $C R I$ untuk jawaban benar disebut 
dengan $C R I \mathrm{~B}$ dan rata-rata nilai $C R I$ untuk jawaban salah disebut dengan CRIS. Hasil bagi antara siswa yang menjawab benar dengan jumlah total siswa disebut dengan fraksi benar (FB).

$$
\begin{gathered}
C R I \mathrm{~B}=\frac{\text { total jumlah CRI dari jawaban benar }}{\text { jumlah siswa yang men jawab benar }} \\
\text { CRIS }=\frac{\text { total jumlah CRI dari jawaban salah }}{\text { jumlah siswa yang menjawab salah }} \\
F B=\frac{\text { jumlah siswa yang menjawab benar }}{\text { total jumlah siswa }}
\end{gathered}
$$

Pada kasus di mana rata-rata $C R I$ mendekati atau sama dengan 2,5 maka fraksi benar digunakan untuk menentukan apakah rata-rata nilai $C R I$ harus digolongkan rendah atau tinggi. Misalnya, jika terjadi rata-rata nilai CRIS yang mendekati atau sama dengan 2,5 dan fraksi benarnya rendah $(<0,5)$, maka CRIS tersebut dapat digolongkan $C R I$ tinggi karena proporsi siswa yang menjawab salah lebih besar. Sebaliknya, jika pada CRIS tersebut fraksi benarnya tinggi $(>0,5)$, maka CRIS tersebut digolongkan CRI rendah karena proporsi siswa yang menjawab benar lebih besar (Hasan, Bagayoko, \& Kelly, 1999).

Pengaruh pembelajaran model guided discovery learning menggunakan alat sederhana yang diberikan selama tiga kali pertemuan dapat diketahui dengan melakukan analisis statistik parametrik menggunakan SPSS 17.0 dengan memperhatikan beberapa asumsi bahwa pengujian ukuran populasi melalui data sampel yaitu data yang akan dianalisis harus berdistribusi normal dan menggunakan data dua kelompok atau lebih yang homogen (Sugiyono, 2014) sebagai berikut:

\section{a) Uji Normalitas}

Uji normalitas dilakukan pada data pretest dengan asumsi bahwa sebelum diberikan perlakuan yang sama pada masing-masing kelas X-2, kelas X-3, dan kelas X4 terlebih dahulu dilihat kenormalan datanya. Kenormalan data dapat diketahui dengan menggunakan beberapa uji statistik, tetapi dalam penelitian ini hanya menggunakan uji Kolmogorov Smirnov dengan taraf signifikansi $\alpha=0.05$ (2-tailed). Bentuk hipotesis untuk uji normalitas menurut Sugiyono (2014) adalah:

$\mathrm{H}_{0}$ : data berasal dari populasi berdistribusi normal.

$\mathrm{H}_{1}$ : data berasal dari populasi tidak berdistribusi normal.

Pada pengujian hipotesis kriteria untuk menolak atau tidak menolak $\mathrm{H}_{0}$ berdasarkan $\mathrm{P}$-value atau istilah Signifinance (Sig) adalah sebagai berikut:

Jika Sig $<\alpha$, maka $\mathrm{H}_{0}$ ditolak.

Jika Sig $>\alpha$, maka $\mathrm{H}_{0}$ diterima. b) Uji Homogenitas

Pengujian homogenitas adalah pengujian mengenai sama tidaknya variansi-variansi dua buah distribusi atau lebih. Uji homogenitas yang digunakan dalam penelitian ini adalah uji Levene dengan taraf signifikansi $\alpha=0.05$ (2-tailed) pengujian hipotesis menurut Santoso S (2014) adalah:

$\mathrm{H}_{0}$ : data berasal dari varians populasi yang sama.

$\mathrm{H}_{1}$ : data berasal dari varians populasi yang tidak sama.

Pada pengujian hipotesis kriteria untuk menolak atau tidak menolak $\mathrm{H}_{0}$ berdasarkan $\mathrm{P}$-value atau istilah Signifinance (Sig) adalah sebagai berikut:

Jika Sig $<\alpha$, maka $\mathrm{H}_{0}$ ditolak.

Jika Sig $>\alpha$, maka $\mathrm{H}_{0}$ diterima.

c) Uji-t Berpasagan

Uji-t berpasangan digunakan untuk membandingkan dua sampel atau lebih yang berpasangan, diartikan sebagai sebuah sampel dengan subjek yang sama, namun mengalami perlakuan berbeda (hasil pretest siswa sebagai data sebelum perlakuan dan hasil posttest siswa sebagai data setelah perlakuan). Uji-t berpasangan menggunakan derajat bebas $\mathrm{n}-1$, di mana $\mathrm{n}$ adalah jumlah sampel dan taraf signifikansi $\alpha=0.05$ (2-tailed). Bentuk hipotesis untuk uji-t menurut Sugiyono (2014) adalah:

$\mathrm{H}_{0}$ : Rata-rata hasil pretest dan hasil posttetest tidak terdapat perbedaan.

$\mathrm{H}_{1}$ : Rata-rata hasil pretest dan hasil posttetest terdapat perbedaan.

pada pengujian hipotesis kriteria untuk menolak atau tidak menolak $\mathrm{H}_{0}$ berdasarkan $\mathrm{P}$-value atau istilah Signifinance (Sig) adalah sebagai berikut:

Jika Sig $>\alpha$, maka $\mathrm{H}_{0}$ diterima.

Jika Sig $<\alpha$, maka $\mathrm{H}_{0}$ ditolak.

\section{Analisis Kendala Pelaksanaan KBM}

Kendala selama pelaksanaan KBM dianalisis dengan deskriptif kualitatif yaitu pengamat dan peneliti memberikan catatan kendala-kendala yang terjadi pada pelaksanaan pembelajaran tiga pertemuan disertai dengan solusi atau saran.

\section{HASIL PENELITIAN DAN DISKUSI}

A. Validitas Pengembangan Perangkat Pembelajaran

Pengembangan perangkat pembelajaran fisika model guided discovery learning menggunakan alat sederhana yang dikembangkan, dikatakan valid apabila memenuhi validitas minimal skor rata-rata 2,6 (Ratumanan dan Lauren, 2006) untuk menurunkan miskonsepsi siswa SMA pada materi fluida statis. Hasil pengembangan perangkat pembelajaran meliputi RPP, 
BAS, LKS, dan soal tes miskonsepsi dapat dilihat pada grafik gambar 2 .

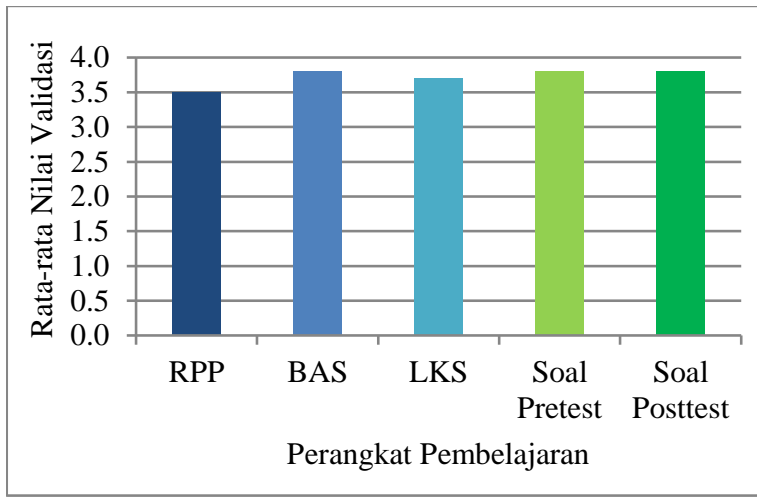

Gambar 2. Hasil validasi pengembangan perangkat pembelajaran fisika

Pencapaian kategori valid dalam pengembangan perangkat pembelajaran dikarenakan pengembangannya telah melalui beberapa tahapan yaitu analisis kebutuhan siswa, analisis siswa, analisis konsep, diskusi dengan guru fisika SMA, telaah pembimbing, dan masukan ketiga validator sehingga perangkat pembelajaran yang telah dikembangkan dapat digunakan dalam pembelajaran fisika untuk menurunkan miskonsepsi siswa SMA pada materi fluida statis.

Tahapan pengembangan pembelajaran memperhatikan karakteristik model dan pendekatan yang digunakan. Peneliti menggunakan perangkat pembelajaran model 4-D menurut Thiagarajan dan Semmel (1975) yang meliputi pendefinisian, perancangan, pengembangan, dan penyebaran. Tahap penyebaran dalam penelitian ini tidak dapat dilaksanakan karena keterbatasan waktu dan biaya, sehingga dalam penelitian ini pengembangan perangkat pembelajaran yang dilaksanakan hanya sampai pada tahap pengembangan. Pengembangan perangkat pembelajaran yang peneliti kembangkan meliputi RPP, BAS, LKS, dan instrumen evaluasi. Pengembangan perangkat pembelajaran yang dikembangkan oleh peneliti telah divalidasi oleh beberapa validator yang kompeten di bidang pendidikan fisika dan telah dinyatakan valid sehingga perangkat pembelajaran yang dikembangkan dapat digunakan untuk penelitian.

\section{B. Kepraktisan Perangkat Pembelajar}

Kepraktisan perangkat pembelajaran dapat diperoleh dari hasil keterbacaan perangkat pembelajaran, hasil keterlaksanaan RPP, dan kendala yang dihadapi.

1) Keterbacaan perangkat pembelajaran

Keterbacaan perangkat pembelajaran diperoleh dari keterbacaan BAS dan LKS merupakan cara untuk memeroleh gambaran kemudahan atau kesulitan siswa memahami BAS dan LKS. Keterbacaan BAS dan LKS diukur menggunakan lembar instrumen keterbacaan BAS dan LKS. Keterbacaan minimal memeroleh skor $40 \%$ (kategori tepat untuk pembelajaran) dapat dilihat pada grafik Gambar 3.

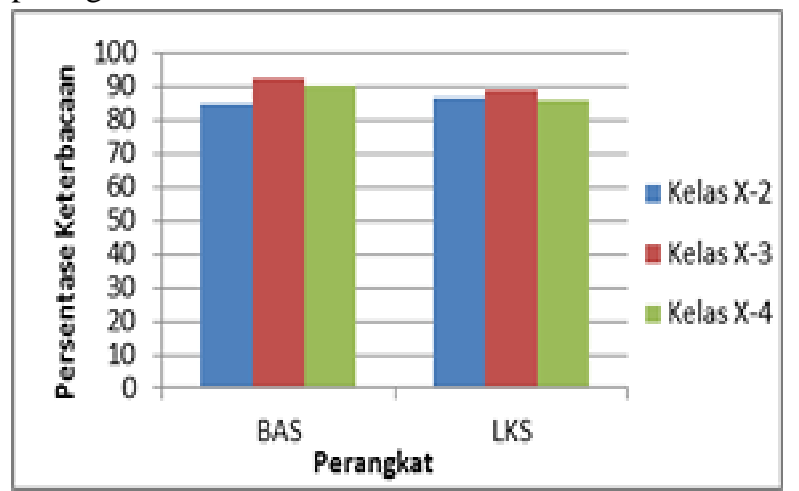

Gambar 3. Hasil keterbacaan perangkat pembelajaran fisika

Keterbacaan perangkat BAS, LKS yang dikembangkan melalui cara mengosongkan beberapa kata-kata kunci di dalam paragraf kemudian siswa diminta untuk melengkapi paragraf tersebut. Jawaban dari siswa dapat terbaca baik bilamana jawaban dalam melengkapi paragraf itu benar dan tingkat keterbacaan perangkat secara keseluruhan adalah total persen dari keseluruhan jawaban siswa yang benar. Persentase keterbacaan perangkat BAS dan LKS yang dikembangkan, diperoleh kelas X-2 keterbacaan BAS $84,67 \%$, kelas X-3 keterbacaan BAS 92,50\% dan kelas X-4 keterbacaan BAS 90,17\%. Pada keterbacaan LKS diperoleh kelas X-2 keterbacaan LKS 86,42\%, kelas X3 keterbacaan LKS 89,33\%, dan kelas X-4 keterbacaan LKS $85,92 \%$. Kesimpulan dari keterbacaan perangkat BAS dan LKS adalah dapat terbaca dengan baik atau keterbacaannya tinggi. Keterbacaan tinggi artinya, dapat dengan mudah dipahami oleh sebagian besar siswa. Keterbacaan disebut sulit jika mempunyai tingkat keterbacaan yang rendah. Keterbacaan rendah artinya, hanya dapat dipahami oleh sebagian kecil siswa (Taylor, 1953; Gilliliand, 1972; dan Harjasujana, 1998).

\section{2) Keterlaksanaan RPP}

Pengamatan dilakukan setiap kali tatap muka oleh dua pengamat yang sudah dilatih sehingga dapat mengoperasikan lembar pengamatan secara benar. Penilaian ini meliputi kegiatan pendahuluan, kegiatan inti, kegiatan penutup, pengelolaan waktu, dan pengamatan suasana kelas. Keterlaksanaan perangkat pembelajaran minimal memeroleh skor 3,5 dikatakan berkategori baik (Suharsimi, 2012), dapat dilihat pada grafik Gambar 4, Gambar 5, dan Gambar 6. 


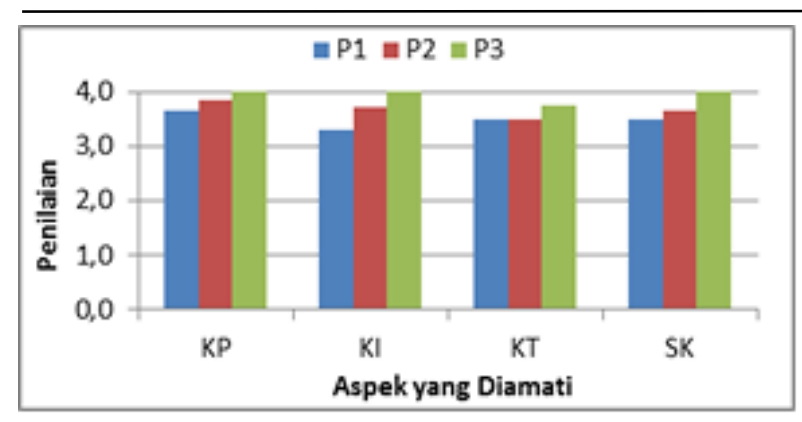

Gambar 4. Hasil keterlaksanaan RPP kelas X-2

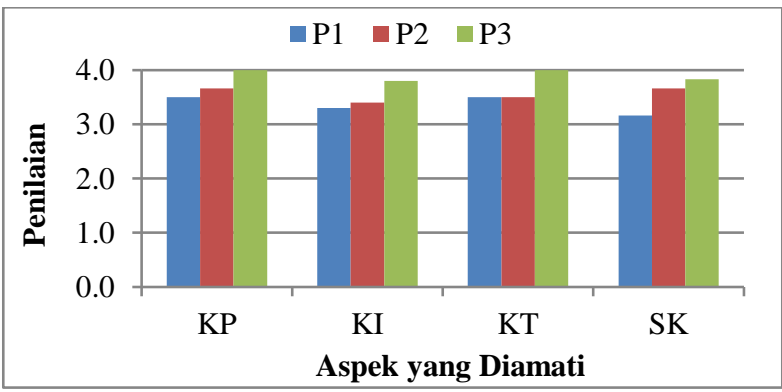

Gambar 5. Hasil keterlaksanaan RPP kelas X-3

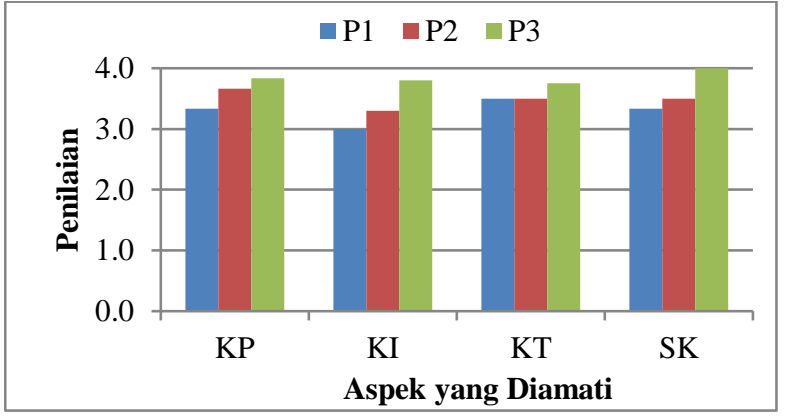

Gambar 6. Hasil keterlaksanaan RPP kelas X-4

Keterangan:

$$
\begin{aligned}
& \mathrm{P} 1=\text { pertemuan pertama } \\
& \mathrm{KP}=\text { kegiatan pendahuluan } \\
& \mathrm{P} 2 \text { = pertemuan kedua } \\
& \mathrm{KI}=\text { kegiatan inti } \\
& \mathrm{P} 3=\text { pertemuan ketiga } \\
& \mathrm{KT}=\text { kegiatan penutup } \\
& \mathrm{SK}=\text { suasana kelas }
\end{aligned}
$$

Beberapa aspek yang diamati, berdasarkan hasil pengamatan dua orang pengamat, secara keseluruhan hasil keterlaksanaan RPP yaitu: 1) kelas X-2 pertemuan pertama mendapat skor rata-rata 3,5 dengan kategori cukup baik, pertemuan kedua mendapat skor rata-rata 3,7 dengan kategori baik, dan pertemuan terakhir mendapat skor rata-rata 3,9 dengan kategori sangat baik. 2) kelas X-3 pertemuan pertama mendapat skor rata-rata 3,4 dengan kategori cukup baik, pertemuan kedua mendapat skor rata-rata 3,6 dengan kategori baik, dan Pertemuan terakhir mendapat skor rata-rata 3,9 dengan kategori baik. 3) kelas X-4 pertemuan pertama mendapat skor rata-rata 3,3 dengan kategori cukup baik, pertemuan kedua mendapat skor rata-rata 3,5 dengan kategori cukup baik, dan pertemuan terakhir mendapat skor rata-rata 3,8 dengan kategori baik (Suharsimi, 2012).

Keterlaksanaan RPP pada kelas X-2, kelas X-3, dan kelas X-4 umumnya mengalami peningkatan efektivitas pada setiap pertemuan yaitu dari pertemuan pertama meningkat ke pertemuan kedua dan meningkat lagi ke pertemuan ketiga. Terjadinya peningkatan keterlaksanaan RPP karena peneliti melakukan evaluasi bersama-sama dengan pengamat disetiap selesai pembelajaran, mengenai hal-hal yang menjadi kekurangan dan berupaya meningkatkan keterlaksanaan pembelajaran pada pertemuan berikutnya. Kesimpulan dari keterlaksanaan RPP pada kelas X-2, kelas X-3, dan kelas X-4 yaitu baik, yang berarti guru mampu mengelola pembelajaran sesuai dengan tahapan-tahapan model guided discovery learning menggunakan alat sederhana. Guru mampu mengorganisir siswa ke dalam pembelajaran aktif dan menyenangkan. Siswa mendapat kesempatan untuk mengeksplorasi pengetahuan awal supaya menemukan sendiri jawaban dari permasalahan yang dihadapi (Carin, 1993; Budiningsih, 2005).

\section{3) Kendala}

Kendala selama KBM dianalisis dengan deskriptif kualitatif yaitu pengamat dan peneliti berdiskusi untuk mengidentifikasi kendala-kendala yang terjadi selama pelaksanaan pembelajaran, kemudian mencari solusi dari kendala-kendala tersebut. Kendala pembelajaran di antaranya yaitu: kendala pertama, beberapa siswa yang memiliki kemampuan akademik kurang ternyata mereka merasa sulit memahami dan melakukan kegiatan penemuan di dalam praktikum. Solusi yang diberikan yaitu guru membimbing intensif atau sebagai fasilitator di dalam praktikum bagi siswa yang memiliki kemampuan akademik kurang. Hal ini sesuai yang ditemukan dalam penelitian Fajar \& Supardi (2013) menemukan beberapa siswa mengalami kesulitan dalam menggunakan KIT karena kemampuan akademik siswa tersebut kurang. Kendala kedua, beberapa siswa yang memiliki kemampuan akademik kurang ternyata mengalami miskonsepsi yang tinggi. Solusi yang diberikan yaitu guru memberi bimbingan intensif, memberikan contoh-contoh fenomena dalam kehidupan sehari-hari yang berhubungan dengan fluida statis bagi siswa yang kurang dalam kemampuan akademik. Bertujuan memastikan pemahaman konsep yang dimiliki siswa tersebut sudah benar atau minimal terjadi penurunan miskonsepsi.

\section{Keefektifan Perangkat Pembelajaran}

Keefektifan perangkat pembelajaran dapat diperoleh dari hasil belajar, penurunan miskonsepsi, aktivitas siswa dan respons siswa. 


\section{1) Hasil belajar}

Hasil belajar siswa dapat diperoleh dari ketuntasan indikator tujuan pembelajaran dan nilai KKM yang diperoleh siswa.

(a) Ketuntasan indikator

Hasil ketuntasan indikator tujuan pembelajaran dapat dilihat pada Tabel 7.

Tabel 7. Ketuntasan Indikator

\begin{tabular}{|c|c|c|l|}
\hline Kelas & $\begin{array}{c}\text { Rata-rata } \\
\text { KI }\end{array}$ & $\begin{array}{c}\text { Rata-rata } \\
\boldsymbol{N} \text {-Gain }\end{array}$ & Keterangan \\
\hline X-2 & 3,63 & 0,85 & Tuntas \\
\hline X-3 & 3,89 & 0,96 & Tuntas \\
\hline X-4 & 3,76 & 0,90 & Tuntas \\
\hline
\end{tabular}

Keterangan: $\mathrm{KI}=$ Ketuntasan Indikator

Indikator yang dipilih sesuai dengan model pembelajaran guided discovery learning menggunakan alat sederhana dan Kurikulum 2013 pada aspek pengetahuan yang merujuk pada revisi taksonomi pendidikan Bloom pada ranah kognitif. Indikator pembelajaran yang disusun dengan urutan hirarki, mulai yang sederhana sampai dengan yang kompleks (Anderson \& Kratwohl, 2013). Indikator pembelajaran dalam penelitian ini merujuk pada kata operasional meliputi: 1) menafsirkan; 2) mendefinisikan; 3) mengklasifikasikan;

4) menerapkan; membandingkan; 6) merangkum; dan 5) menyimpulkan.

Penerapan hasil pengembangan perangkat pembelajaran model guided discovery learning menggunakan alat sederhana bahwa semua indikator pembelajaran telah mencapai ketuntasan pada aspek pengetahuan pada kelas X-2, kelas X-3, dan kelas X-4 terlihat pada hasil posttest siswa dan rata-rata $N$-Gain yang merupakan derajat pengaruh pembelajaran terhadap miskonsepsi siswa berkategori tinggi dengan keterangan dapat melanjutkan ke KD selanjutnya (Hake, 1999).

\section{(b) Nilai KKM}

Nilai KKM masing-masing siswa kelas X-2, kelas X-3, dan kelas X-4 SMA Negeri 19 Surabaya dinyatakan mencapai nilai KKM untuk mata pelajaran fisika bila mendapat skor $\geq 75$ (Kemendikbud, 2013) dapat dilihat pada Tabel 8 .

Tabel 8. Ketuntasan hasil belajar

\begin{tabular}{|l|l|c|l|l|}
\hline $\begin{array}{l}\text { Kel } \\
\text { as }\end{array}$ & $\begin{array}{l}\text { Skor } \\
\text { Rata- } \\
\text { rata } \\
\text { Individu }\end{array}$ & $\begin{array}{l}\text { Ketuntasan } \\
\text { Kalsikal }\end{array}$ & $\begin{array}{l}\text { Rata- } \\
\text { rata } \boldsymbol{N} \text { - } \\
\text { Gain }\end{array}$ & Ket \\
\hline X-2 & 90,71 & $100 \%$ & 0,87 & Tuntas \\
\hline X-3 & 97,26 & $100 \%$ & 0,96 & Tuntas \\
\hline X-4 & 94,27 & $100 \%$ & 0,92 & Tuntas \\
\hline
\end{tabular}

Nilai pretest yang diperoleh siswa pada masingmasing kelas menunjukkan kemampuan awal siswa secara individu memeroleh ketuntasan individual yang rendah dengan predikat tidak tuntas dan juga diperoleh ketuntasan klasikal sebesar 0\%. Kemudian diberikan perlakukan dengan model guided discovery learning menggunakan alat sederhana sebanyak tiga kali pertemuan kemudian diberikan posttest. Hasil posttest yang diperoleh siswa pada masing-masing kelas menunjukkan secara individu semua siswa mencapai KKM dan secara klasikal memeroleh ketuntasan hasil belajar $100 \%$, dan berdasarkan nilai $\mathrm{N}$-Gain rata-rata berkategori tinggi, hanya saja ada beberapa siswa yang memeroleh nilai $\mathrm{N}$-Gain berkategori sedang. Siswasiswa yang memeroleh $\mathrm{N}$-Gain kategori sedang, disebabkan karena siswa tersebut memiliki aktivitas pembelajaran yang rendah bila di bandingkan dengan siswa-siswa yang memperoleh ketuntasan belajar dengan nilai $\mathrm{N}$-Gain kategori tinggi, di mana memiliki aktivitas pembelajaran yang tinggi. Hasil penelitian ini sejalan dengan hasil penelitian yang dilakukan oleh Ratunguri (2001) menyimpulkan bahwa model pembelajaran berorientasi konstruktivisme dapat meningkatkan hasil belajar siswa dan Syamsudini (2002) menyimpulkan bahwa metode discovery learning efektif meningkatkan hasil belajar siswa.

2) Penurunan Miskonsepsi Siswa

Tabel 9. Penurunan miskonsepsi berdasarkan konsep

\begin{tabular}{|l|l|l|l|}
\hline \multirow{2}{*}{\multicolumn{1}{|c|}{ Konsep }} & \multicolumn{3}{|c|}{ Persentase Penurunan MK } \\
\cline { 2 - 4 } & Kls X- & Kls X-3 & Kls X-4 \\
\hline 1. Massa Jenis & 73,33 & 53,81 & 49,46 \\
\hline $\begin{array}{l}\text { 2. Tekanan } \\
\text { Hidrostatis }\end{array}$ & 44,76 & 18,57 & 35,44 \\
\hline 3. Prinsip Pascal & 57,62 & 16,67 & 35,51 \\
\hline $\begin{array}{l}\text { 4. Prinsip } \\
\text { Archimedes }\end{array}$ & 61,43 & 9,05 & 10,75 \\
\hline
\end{tabular}

Tabel 10. Penurunan miskonsepsi masing-masing siswa

\begin{tabular}{|c|c|c|c|}
\hline \multirow{2}{*}{ Kelas } & \multicolumn{3}{|c|}{ Persentase Miskonsepsi } \\
\cline { 2 - 4 } & Pretest & Posttest & Penurunan \\
\hline X-2 & 64,64 & 5,36 & 59,29 \\
\hline X-3 & 27,02 & 2,50 & 24,52 \\
\hline X-4 & 37,62 & 5,12 & 32,50 \\
\hline
\end{tabular}

Tabel 11. Penurunan miskonsepsi berdasarkan nilai FB

\begin{tabular}{|l|l|l|l|l|l|l|}
\hline \multirow{2}{*}{ Kelas } & \multicolumn{3}{|l|}{ Pretest } & \multicolumn{3}{l|}{ Posttest } \\
\cline { 2 - 7 } & FB & K & P & FB & K & P \\
\hline X-2 & 0,28 & T & BS & 0,97 & R & BB \\
\hline X-3 & 0,29 & T & BS & 0,97 & R & BB \\
\hline X-4 & 0,30 & T & BS & 0,94 & R & BB \\
\hline
\end{tabular}

Keterangan:
$\mathrm{FB}=$ Fraksi Benar;
$\mathrm{K}=$ Kategori;
$\mathrm{T}=$ Tinggi;
$\mathrm{BS}=$ Banyak Salah;
$\mathrm{P}=$ Proporsi;
$\mathrm{R}=$ Renda;
$\mathrm{BB}=$ Banyak Benar 
Penurunan miskonsepsi yang dilihat dari beberapa bagian meliputi konsep materi, masing-masing siswa dan nilai FB dari analisis $C R I$ diperoleh beberapa fakta: 1) fakta dari hasil pretest yaitu rendahnya pemahaman konsep siswa yang disebabkan oleh adanya miskonsepsi dan kekurangmantapan konsepsi siswa, hal ini terjadi karena sebelum siswa masuk dalam pembelajaran fisika, mereka sudah banyak berpengalaman dengan peristiwa-peristiwa fisika dalam kehidupan sehari-hari sehingga sudah terbangun suatu konsepsi yang bisa saja benar atau belum tentu sama dengan konsepsi fisikawan, konsep semacam itu disebut prakonsepsi (Berg, 1991; Hammer, 1996; Ibrahim, 2012). 2) fakta dari hasil posttest yaitu kegiatan belajar mengajar menggunakan model guided discovery learning menggunakan alat sederhana membuat siswa terlibat langsung secara aktif dalam proses menemukan jawaban sendiri dari permasalahan yang dihadapi, sehingga siswa semakin menguasai konsep dengan benar (Bruner, 1990; Carin, 1993; Budiningsih, 2005; Dahar, 2011). 3) siswa mengalami peningkatan penguasaan konsep atau tahu konsep mengakibatkan terjadinya penurunan miskonsepsi siswa serta ketuntasan belajar siswa telah mencapai KKM baik secara individual maupun klasikal (Berg, 1991; Suparno, 2005; Ibrahim, 2010).

Hasil uji normalitas menggunakan uji Kolmogorov Smirnov seperti terlihat pada Tabel 12.

Tabel 12. Hasil uji normalitas

\begin{tabular}{|l|l|l|c|}
\hline Sampel & \multicolumn{1}{l|}{$\boldsymbol{\alpha}$} & \multicolumn{1}{l|}{ Sig } & Keterangan \\
\hline Kelas X-2 & 0,05 & 0,124 & Normal \\
\hline Kelas X-3 & 0,05 & 0,459 & Normal \\
\hline Kelas X-4 & 0,05 & 0,645 & Normal \\
\hline
\end{tabular}

Berdasarkan hasil uji Kolmogorov Smirnov pada pengujian hipotesis $\mathrm{H}_{0}$ dan $\mathrm{H}_{1}$, diperoleh yaitu sig $>\alpha$ maka $\mathrm{H}_{0}$ diterima, berarti data berasal dari populasi berdistribusi normal. Hal tersebut dimaknai bahwa keadaan sampel yang diambil mirip dengan populasi yang sebenarnya.

Hasil uji homogenitas menggunakan uji Levene seperti terlihat pada Tabel 13 .

Tabel 13. Hasil uji homogenitas

\begin{tabular}{|l|l|l|c|}
\hline Sampel & \multicolumn{1}{l|}{$\boldsymbol{\alpha}$} & \multicolumn{1}{l|}{ Sig } & Keterangan \\
\hline Kelas X-2 & 0,05 & 0,166 & Homogen \\
\hline Kelas X-3 & 0,05 & 0,166 & Homogen \\
\hline Kelas X-4 & 0,05 & 0,166 & Homogen \\
\hline
\end{tabular}

Berdasarkan hasil uji Levene pada pengujian hipotesis $\mathrm{H}_{0}$ dan $\mathrm{H}_{1}$, diperoleh yaitu sig > $\alpha$ maka $\mathrm{H}_{0}$ diterima, berarti data berasal dari varians populasi yang homogen. Hal tersebut menunjukkan bahwa semua siswa memiliki kemampuan pengetahuan yang sama pada awal pembelajaran.
Hasil uji-t berpasangan (paired sample- $t$ test) seperti terlihat pada Tabel 14.

Tabel 14. Hasil uji-t berpasangan

\begin{tabular}{|c|c|l|c|c|}
\hline Sampel & $\mathbf{t}_{\text {tabel }}$ & $\mathbf{t}_{\text {hitung }}$ & $\boldsymbol{\alpha}$ & sig \\
\hline Kelas X-2 & 2,042 & 27,286 & 0,05 & 0.000 \\
\hline Kelas X-3 & 2,042 & 34,111 & 0,05 & 0.000 \\
\hline Kelas X-4 & 2,042 & 34,852 & 0,05 & 0.000 \\
\hline
\end{tabular}

Berdasarkan hasil uji-t berpasangan pada pengujian hipotesis $\mathrm{H}_{0}$ dan $\mathrm{H}_{1}$, diperoleh yaitu sig $<\alpha$ maka $\mathrm{H}_{0}$ ditolak atau $\mathrm{t}_{\text {tabel }}<\mathrm{t}_{\text {hitung }}$ maka $\mathrm{H}_{0}$ ditolak, berarti rata-rata hasil pretest dan hasil posttest terdapat perbedaan signifikan (Suharsimi, 2013; Sugiyono, 2014). Hal tersebut menunjukkan bahwa data pretest sebelum diberikan perlakukan pembelajaran dan data posttest setelah diberikan perlakukan pembelajaran diketahui bahwa perlakuan pembelajaran model guided discovery learning mempunyai pengaruh meningkatkan kemampuan pengetahuan yang dimiliki siswa dan dapat menurunkan miskonsepsi siswa.

\section{3) Aktivitas Siswa}

Aktivitas siswa diperoleh dari pengamatan kedua pengamat di setiap pertemuan. Secara dominan menunjukkan aktivitas siswa relevan dengan model guided discovery learning menggunakan alat sederhana. Aktivitas siswa tersebut ditunjukkan dengan siswa aktif melakukan eksperimen, menganalisis hasil eksperimen, berdiskusi, memperhatikan peragaan, dan penjelasan guru sebagai fasilitator dalam pembelajaran. Aktivitas siswa di setiap pertemuan terjadi peningkatan dari pertemuan pertama, kedua, dan ketiga, tetapi masih ditemukan di setiap pertemuan beberapa siswa melakukan perilaku yang tidak relevan namun perilaku tersebut mengalami penurunan dari pertemuan pertama, kedua, dan ketiga.

\section{4) Respons Siswa}

Informasi tentang respons siswa terhadap kegiatan belajar mengajar diperoleh dari angket yang diberikan ke siswa setelah diberikan perlakukan pembelajaran sebanyak tiga kali pertemuan. Hasil respons siswa ratarata memberikan respons yang baik terhadap komponen pembelajaran meliputi BAS, LKS, soal tes miskonsepsi, cara guru mengajar dan suasana kelas dengan menerapkan model guided discovery learning menggunakan alat sederhana. Terlihat dari motivasi siswa mengikuti kegiatan pembelajaran dan semangat untuk belajar sehingga siswa dapat fokus untuk menemukan jawaban atas rasa keingintahuannya melalui proses mentalnya sendiri. Siswa dapat lebih mudah memahami apa yang diajarkan dan apa yang mereka pelajari. Dorongan siswa yang berasal dari dalam diri sendiri untuk belajar, menyebabkan siswa 
akan melakukan percobaan dengan teliti dan bertanggungjawab. Sehingga mereka dapat memaknai apa yang mereka peroleh. Hal tersebut sejalan dengan pendapat Bell (1978) dan Carin (1993).

\section{KESIMPULAN}

Berdasarkan hasil analisis, diskusi, dan pembahasan, maka dapat dibuat kesimpulan bahwa perangkat pembelajaran fisika model guided discovery learning menggunakan alat sederhana yang dikembangkan telah memenuhi kriteria validitas, kepraktisan, dan keefektifan sehingga layak digunakan untuk mereduksi miskonsepsi siswa SMA pada materi fluida statis.

Saran dapat dikemukakan oleh peneliti berdasarkan penelitian yang telah dilakukan adalah masih terdapat beberapa siswa yang mempertahankan (resistensi) miskonsepsi yang dialami. Sehingga diharapkan untuk penelitian lanjutan memperhatikan tindak lanjut bagaimana mengatasi siswa yang masih resistensi terhadap miskonsepsi sehingga dapat diubah menjadi konsep yang ilmiah.

\section{REFERENSI}

Anderson, L. W., \& Krathwohl, D. R. (2012). Pembelajaran, pengajaran dan assesmen revisi taksonomi pendidikan Bloom. Yogyakarta: Pustaka Pelajar.

Arifin, Z. (2010). Evaluasi pembelajaran prinsip, teknik, dan prosedur. Bandung: Remaja Rosdakarya.

Bell, F. (1978). Teaching and learning mathematics in secondary school. New York: Wm C Brown Company Publiser.

Berg, V d Euwe. (1991). Miskonsepsi fisika dan remidiasi. Salatiga: Universitas Kristen Satya Wacana.

Bruner, J. (1990). Acts of meaning. Cambridge: Harvard University Press.

Budiningsih, A. C. (2005). Belajar dan pembelajaran. Jakarta: Rineka Cipta.

Carin, A. A. (1993). Teacher science through discovery ( 7 th ed.). New York: Macmillan Publishing Company.

Dahar, Ratna Wilis. (2011). Teori-teori belajar dan pembelajaran. Jakarta: Erlangga.

Fajar, D. M., \& Supardi, Z. I. (2013). Pengaruh penggunaan model pembelajaran inkuiri (Inquiry Learning) terhadap penurunan miskonsepsi pada materi listrik dinamis kelas X SMAN 2 Jombang. Jurnal inovasi pendidikan fisika, Vol 02 Tahun 2013, 24-39.

Gilliliand, J. (1976). Readabbility. London: Horder and Stoughton.

Hammer, D. (1996). More than misconceptions: multiple perspectives on student knowledge and reasoning and appropriate role for education research. Am. J. Phys, pp.1316-1325.

Harjasujana, A.S. dan Damaianti, V.S. (2003). Membaca dalam teori dan praktik. Bandung: Mutiara.

Hasan, S., Bagayoko, D., \& Kelly, E. L. (1999). Misconseptions and The Certainly of Response Index (CRI). Journal physics education, 294-299.

Ibrahim. (2012). Konsep, miskonsepsi dan cara pembelajarannya. Surabaya: Unesa University Press.

Kemendikbud. (2013). Peraturan Menteri Pendidikan RI No. 32 Tahun 2013 tentang perubahan Peraturan Pemerintah No. 19 Tahun 2005 tentang Standar Nasional Pendidikan. Jakarta: Depdikbud.

Kim, Y. e. (2006). Students' Cognitif Conflict and Conceptual Change in a Physics by Inquiry Class. Journal of American Institute of Physics, Vol. 02, No. 6, pp. 0311-0735

Klammer, J. (1998). an overview of techniques for indentifiying acknowledging and overcoming alternate conceptions in physics education. Columbia: Teachers College-Columbia University.

Nur, M. (2008). Pengajaran berpusat kepada siswa dan pendekatan konstruktivis dalam pengajaran. Surabaya: Unesa University Press.

Riduwan. (2005). Skala pengukuran variabel-variabel penelitian. Bandung: AlfaBeta.

Ratumanan, T. G., \& Laurens. (2006). Evaluasi hasil belajar yang relevan dengan Kurikulum Berbasis Kompetensi. Surabaya: Unesa University Press.

Ratunguri, Yusak. (2011). Pengaruh pembelajaran berorientasi konstruktivisme, konflik kognitif, dan praktikum terhadap profil dan reduksi miskonsepsi IPA SD Kelas IV. (Tesis Magister Pendidikan Dasar tidak dipublikasikan). Surabaya: Pascasarjana Unesa.

Santoso S. (2014). Statistik parametrik konsep dan aplikasi dengan SPSS. Jakarta: PT Elex Media Komputindo.

Suharsimi Arikunto. (2012). Dasar-dasar evaluasi pendidikan edisi 2. Jakarta: Bumi Aksara.

Suparno, P. (2005). Miskonsepsi dan perubahan konsep dalam pendidikan fisika. Jakarta: Grasindo.

Sugiyono. (2014). Metode penelitian kombinasi. Bandung: AlfaBeta.

Syamsudini. (2012). Aplikasi metode discovery learning efektif untuk meningkatkan kemampuan memecahkan masalah, motivasi belajar dan daya ingat siswa. (Tesis Magister Pendidikan Sains tidak dipublikasikan). Surabaya: Pascasarjana Unesa.

Thiagarajan \& Semmel. (1974). Instructional development for traning teacher of exceptional children a sourcebook. Indiana: Indiana University.

Taylor, W.L. (1953). Cloze procedure a new tool for measuring readability". Journal Quarterly, Vol. 30. Pp. 415-433. 